\title{
Tingkat Hygiene Penjamah Makanan di Pelabuhan Kelas I Medan dan Faktor yang Mempengaruhi
}

\author{
Togar Pangihutan Hutasoit \\ Program Studi Ilmu Kesehatan Masyarakat Universitas Sari Mutiara Indonesia \\ Jl. Kapten Muslim No 79, Medan 20123 \\ Email : togar pangihutan@gmail.com
}

\begin{abstract}
Abstrak
Higiene sanitasi adalah upaya untuk mengendalikan faktor risiko terjadinya kontaminasi terhadap makanan, baik yang berasal dari bahan makanan, orang, tempat dan peralatan agar aman dikonsumsi. Higiene sanitasi jasa boga, bahan makanan semua bahan baik terolah maupun yang tidak digunakan dalam pengolahan makanan, termasuk bahan tambahan makanan. Jenis penelitian adalah merupakan penelitian observasional dengan pendekatan cross sectional.Penelitian ini dilakukan di Kantor Kesehatan Pelabuhan Kelas I Medan, dimana KKP Kelas I Medan ini memiliki wilayah perimeter dan bufer. Populasi dalam penelitian ini adalah seluruh penjamah makanan pada rumah makan / kantin di wilayah perimeter dan buffer KKP Kelas I Medan. Jumlah sampel dalam peneltian ini sebanyak 87 orang. Hasil menunjukkan tidak ada hubungan antara kelompok umur, jenis kelamin, lama kerja penjamah makanan dengan hygiene penjamah makanan. Uji regresi menunjukkan faktor pengetahuan sangat berhubungan dengan hygiene penjamah makanan dengan nilai $p=0,000$, faktor sikap dengan nilai $p=0,000$. Sedangkan faktor tindakan tidak berhubungan dengan hygiene penjamah makanan dengan nilai $p=0,3 \mid 2$. Ada hubungan antara pengetahuan, sikap, tindakan penjamah makanan dengan hygiene penjamah makanan. Faktor pengetahuan, sikap sangat berhubungan dengan hygiene penjamah makanan. Diharapkan bagi penjamah makanan agar meningkatkan pengetahuannya dengan mengikuti pelatihan tentang sanitasi makanan, yang dilakukan oleh instansi terkait seperti KKP Kelas I Medan, kesyahbandaran dan otoritas pelabuhan.
\end{abstract}

Kata kunci : Hygiene, Penjamah Makanan, Sanitasi Makanan

\begin{abstract}
Hygienic sanitation is an attempt to handle some risk factors for the incidence of food contamination, either comes from food stuffs, human beings, places, and food wares in order to be safe to consume. It includes catering service, cooked or uncooked food stuffs, including processing food and food supplements. The objective of the research was to find out the factors which were correlated with the hygienic level of food touches in the working area of KKP (Port Health Office) Class I, Medan. The research used descriptive method. The samples were 84 respondents. The result of the research showed that there was no correlation of age group, sex, the length of service with the hygiene of food touches. There was the correlation of food touches' knowledge, attitude, and action with their hygiene. The factors of knowledge and attitude had the most dominant correlation with food touches' hygiene. It is recommended that food touches increase their knowledge by participating in training about food sanitation held by related agencies such as KKP Class I, Medan, Office of the Harbormaster, and Port Authority.
\end{abstract}

Keywords : Hygiene, Food Sanitation, Food Touches' 


\section{Pendahuluan}

Pembangunan di Indonesia pada umumnya adalah pembangunan Indonesia seutuhnya dan pembangunan masyarakat seluruhnya untuk mewujudkan suatu masyarakat yang adil dan makmur serta merata baik materil maupun spiritual dengan berazaskan Pancasila dan UndangUndang Dasar 1945. Pembangunan yang dilaksanakan pemerintah disamping untuk mencapai kebutuhan lahiriah seperti sandang, pangan, maupun perumahan dan kesehatan juga menjaga keselarasan antara kebutuhan rohaniah. Di dalam UndangUndang Republik Indonesia Nomor 23 tahun 1992 pada Bab V pasal 10 menyatakan bahwa untuk mewujudkan derajat kesehatan yang optimal diselenggarakan upaya kesehatan yang mencakup upaya peningkatan (promotif), pencegahan (preventif), penyembuhan (kuratif), dan pemulihan (rehabilitatif) yang bersifat menyeluruh, terarah, terpadu dan berkesinambungan. Upaya kesehatan tersebut bertujuan untuk meningkatkan status kesehatan individu maupun masyarakat dan dilaksanakan oleh pemerintah dengan mengikutsertakan masyarakat. Sedangkan derajat kesehatan merupakan hasil interaksi dari 4 (empat) faktor yaitu faktor lingkungan, perilaku, pelayanan kesehatan, dan keturunan. ${ }^{1}$

$$
\text { Menurut Peraturan Menteri }
$$

Kesehatan

No.1096/MENKES/PER/VI/2011 Sanitasi makanan merupakan usaha pencegahan yang menitikberatkan kegiatan dan tindakan yang perlu untuk membebaskan makanan dan minuman dari segala bahaya yang mengganggu atau merusak kesehatan. Dengan demikian pengawasan terhadap makanan dan minuman harus dilakukan secara rutin karena makanan bisa menjadi media perantara penularan penyakit.

Masalah keamanan pangan biasanya dimunculkan karena produk pangan terpapar dengan lingkungan yang kotor sehingga pangan menjadi tercemar oleh bahan-bahan yang dapat membahayakan kesehatan manusia. ${ }^{2}$ Beberapa contoh bahan-bahan berbahaya, misalnya mikroba patogen yang menyebabkan orang menjadi sakit atau keracunan, cemaran kimia yang dapat menimbulkan penyakit akut maupun kronis, serta bahan-bahan asing yang secara fisik dapat mencelakakan konsumen. $^{3}$

Makanan merupakan kebutuhan pokok bagi manusia akan tetapi makanan yang tidak sehat dapat merugikan manusia. Sistem pengelolaan makanan dan minuman yang kurang higienis dapat menyebabkan makanan dan minuman itu berperan sebagai sumber penyakit (agent), pembawa penyakit (vehicle) serta media perantara penyebaran penyakit. Pengolahan makanan adalah rangkaian kegiatan yang meliputi penerimaan bahan mentah atau makanan terolah, pembuatan, pengubahan bentuk, pengemasan, pewadahan, pengangkutan dan penyajian. Apabila pengolahan makanan dan minuman telah ditangani dengan baik dari segi sanitasinya maka dapat mengurangi timbulnya peningkatan penyakit yang disebabkan oleh makanan dan minuman tersebut. Dengan demikian maka dapat dikatakan sanitasi makanan berperan penting dalam masalah kesehatan. ${ }^{4}$

Penyakit yang disebabkan oleh makanan salah satunya adalah keracunan makanan. Peristiwa keracunan makanan yang terjadi di perusahaan maupun acara resepsi pernikahan yang diduga disebabkan oleh makanan catering yang disajikan. Peristiwa keracunan makanan siap santap atau siap saji memang seringkali terjadi ketika makanan tersebut dimasak dalam skala besar untuk orang banyak. Di Negara maju seperti di Amerika Serikat, wabah (outbreak) keracunan makanan yang disebabkan oleh pathogen asal pangan juga paling banyak (70\%) disebabkan oleh makanan siap santap olahan industry jasa boga. Bahkan di negara maju mengalami keracunan pangan merupakan penyebab kematian, kontaminasi ulang dari pekerja adalah faktor yang cukup sering (3\%) berkontribusi pada peristiwa keracunan 
dan tidak tepatnya proses pendinginan setelah pemasakan $(30 \%) .^{5}$

Pengawasan secara rutin terhadap pengolah makanan diharapkan dapat mengurangi dan memperkecil angka kesakitan yang disebabkan kurangnya hygiene dan sanitasi pada pengolahan makanan yang kurang diperhatikan dengan baik. Dampak negatif yang diakibatkan adalah penyakit dysentri, typus, saluran pencernaan bahkan kadang menimbulkan kematian akibat keracunan makanan.

Sesuai dengan International Health Regulation (IHR) tahun 2005 yang diberlakukan 15 Juni Tahun 2007 dengan perhatian kepada Public Health Emergency Of International Concern /PHIEC (masalah kedaruratan kesehatan masyarakat yang menjadi perhatian global) memberikan perhatian khusus untuk wilayah pelabuhan dengan menetapkan persyaratan kapasitas inti bandara, pelabuhan dan perlintasan darat agar setiap saatmenjamin lingkungan yang aman bagi para pelaku perjalanan yang menggunakan fasilitas yang ada di pintu masuk, termasuk pengadaan air minum, tempat makanan, fasilitas catering pesawat udara, toilet umum, fasilitas pembuangan sampah cair dan padat yang memadai, dan area berpotensi risiko lainnya, dengan melaksanakan pemeriksaan secara berkala dan sejauh dapat dilakukan menyediakan personel terlatih dalam program sanitasi dan dampak risiko lingkungan. ${ }^{6}$

Untuk mencapai tujuan tersebut Kantor Kesehatan Pelabuhan mempunyai kewajiban terhadap pelaksanaan International Health Regulation (IHR) yang diterima oleh pemerintah Indonesia tanpa syarat. Kantor Kesehatan Pelabuhan mempunyai tugas utama untuk melaksanakan pencegahan masuknya penyakit karantina dan penyakit menular tertentu melalui kapal laut/pesawat udara, pemeliharaan dan peningkatan sanitasi lingkungan di pelabuhan laut serta sebagai kewajiban dalam dunia international mencegah penularan penyakit karantina dan penyakit menular tertentu yang salah satunya adalah pengawasan sanitasi di wilayah pelabuhan. ${ }^{6}$

Pengawasan sanitasi tempat-tempat umum, GBPL (Gedung Bangunan Perusahaan dan Lingkungan) dalam hal ini adalah rumah makan ataupun kantin di wilayah pelabuhan yang dilakukan oleh Kantor Kesehatan Pelabuhan Kelas I Medan adalah pengawasan rutin terhadap hygiene dan sanitai rumah makan/kantin.

Berdasarkan Profil Kantor Kesehatan Pelabuhan Kelas I Medan Tahun 2015 diperoleh bahwa $78 \%$ sanitasi rumah makan / kantin memenuhi syarat kesehatan dan $22 \%$ sanitasi rumah makan / kantin tidak memenuhi syarat kesehatan. Dari hasil pengamatan yang dilakukan oleh staf KKP Kelas I Medan faktor yang menyebabkan tidak memenuhi syarat nya rumah makan / kantin adalah tempat sampah yang tidak memenuhi syarat (tidak memiliki tutup dan tidak dilapisi oleh plastik, tingginya tingkat kepadatan lalat $>10$ ekor), untuk hygiene penjamah makanan belum pernah di teliti tetapi pada tahun 2016 telah dilaksanakan pemeriksaan rectal swab terhadap 7 (tujuh) orang penjamah makanan dan keseluruhannya negatif atau tidak mengandung bakteri salmonella. Hasil pengamatan yang penulis lakukan dilapangan, masih ada penjamah makanan yang tidak memakai pakaian khusus ( celemek, penutup rambut) dan masih memakai perhiasan (tidak cincin kawin) serta merokok pada saat pengolahan makanan. Atas dasar ini penulis tertarik untuk melaksanakan penelitian tentang hygiene penjamah makanan.

\section{Metode Penelitian}

Jenis penelitian adalah merupakan penelitian observasional dengan pendekatan cross sectional yaitu suatu penelitian di mana variabel-variabel yang termasuk faktor-faktor hygeie dan sanitasi penjamah makanan dan variabel-variabel yang termasuk efek diobservasi sekaligus dilakukan pada waktu yang sama. $^{7}$ Penelitian ini dilakukan di Kantor 
Kesehatan Pelabuhan Kelas I Medan, dimana KKP Kelas I Medan ini memiliki wilayah perimeter dan bufer.

Populasi dalam penelitian ini adalah seluruh penjamah makanan pada rumah makan / kantin di wilayah perimeter dan buffer KKP Kelas I Medan. Jumlah sampel dalam peneltian ini sebanyak 87 orang.

\section{Hasil Penelitian \\ Analisis Univariat}

Dari tabel di atas dapat dilihat bahwa kelompok umur > 30 Tahun sebanyak 71 orang $(84,5 \%)$. Jenis kelamin perempuan sebanyak 80 orang $(95,2 \%)$. Lama kerja penjamah makanan lama kerja $>=5$ Tahun sebanyak 65 orang $(77,4 \%)$. Pengetahuan penjamah makanan dengan kategori baik sebanyak 65 orang $(77,4 \%)$. Sikap penjamah makanan dengan kategori tingkat sikap dengan kategori baik sebanyak 66 orang $(78,6 \%)$. Tindakan penjamah makanan dengan kategori tingkat tindakan dengan kategori baik sebanyak 65 orang $(77,4 \%)$. Hygiene penjamah makanan dengan kategori hygiene penjamah makanan dengan kategori sesuai sebanyak 68 orang $(81,0 \%)$.

Dari tabel 2 diatas dapat dilihat bahwa hasil uji statistik dengan menggunakan uji chi-square diperoleh bahwa nilai $\mathrm{p}=0.470(\mathrm{p}>0,05)$ hal ini

menunjukkan bahwa tidak ada hubungan antara kelompok umur penjamah makanan dengan hygiene penjamah makanan. Hasil uji statistik dengan menggunakan uji chisquare diperoleh bahwa nilai $\mathrm{p}=0.578$ ( $\mathrm{p}$ $>0,05)$ hal ini menunjukkan bahwa tidak ada hubungan antara jenis kelamin penjamah makanan dengan hygiene penjamah makanan. Hasil uji statistik dengan menggunakan uji chi-square diperoleh bahwa nilai $\mathrm{p}=0.484(\mathrm{p}>0,05)$ hal ini menunjukkan bahwa tidak ada hubungan antara lama kerja penjamah makanan dengan hygiene penjamah makanan.

Table 1. Distribusi Frekuensi Variabel yang Diteliti

\begin{tabular}{llcc}
\hline Variabel & Kategori & n & \% \\
\hline Umur & $<=30$ Tahun & 13 & 15.5 \\
& $>$ 30 Tahun & 71 & 84.5 \\
Jenis kelamin & Laki-Laki & 4 & 4,8 \\
& Perempuan & 80 & 95,2 \\
Lama kerja & Lama(>=5 Th) & 65 & 77,4 \\
& Baru(<5 Th) & 19 & 22,6 \\
Pengetahuan & Kurang & 19 & 22,6 \\
& Baik & 65 & 77,4 \\
Sikap & Kurang & 18 & 22,6 \\
\multirow{3}{*}{ Tindakan } & Baik & 66 & 78,6 \\
& Kurang & 19 & 22,6 \\
Hygiene & Baik & 65 & 77,4 \\
& Tidak Sesuai & 16 & 19,0 \\
& Sesuai & 68 & 81,0 \\
\hline
\end{tabular}

Tabel 2. Hubungan Antara Kelompok Umur Dengan Hygiene Penjamah Makanan di Kantor Kesehatan Pelabuhan Kelas I Medan Tahun 2017

\begin{tabular}{|c|c|c|c|c|c|c|}
\hline \multirow{3}{*}{ Variabel } & \multirow{3}{*}{ Kategori } & \multicolumn{4}{|c|}{ Hygiene Penjamah Makanan } & \multirow{3}{*}{$\mathbf{P v}$} \\
\hline & & \multicolumn{2}{|c|}{ Tidak Sesuai } & \multicolumn{2}{|c|}{ Sesuai } & \\
\hline & & $\mathbf{n}$ & $\%$ & n & $\%$ & \\
\hline \multirow[t]{2}{*}{ Umur } & $<=30$ Tahun & 3 & 21,3 & 10 & 76,9 & 0,470 \\
\hline & $>30$ Tahun & 13 & 18,3 & 58 & 81,7 & \\
\hline \multirow[t]{2}{*}{ Jenis kelamin } & Laki-Laki & 1 & 25,0 & 3 & 75,0 & 0.578 \\
\hline & Perempuan & 15 & 18,8 & 65 & 81,3 & \\
\hline \multirow[t]{2}{*}{ Lama kerja } & Baru ( < 5 Tahun $)$ & 3 & 15,8 & 16 & 84,2 & 0.484 \\
\hline & Lama( $>=5$ Tahun $)$ & 13 & 20,0 & 52 & 80,2 & \\
\hline \multirow[t]{2}{*}{ Pengetahuan } & Kurang & 13 & 68,4 & 6 & 31,6 & 0,000 \\
\hline & Baik & 3 & 4,6 & 62 & 95,4 & \\
\hline \multirow[t]{2}{*}{ Sikap } & Kurang & 12 & 66,7 & 6 & 33,3 & 0,000 \\
\hline & Baik & 4 & 6,1 & 62 & 93,9 & \\
\hline \multirow[t]{2}{*}{ Tindakan } & Kurang & 8 & 42,1 & 11 & 57,9 & 0,007 \\
\hline & Baik & 8 & 12,3 & 57 & 87,7 & \\
\hline
\end{tabular}


Table 3. Analisis Multivariat Faktor-Faktor Yang Berhubungan Dengan Hygiene Penjamah Makanan Di Kantor Kesehatan Pelabuhan Kelas I Tahun 2017

\begin{tabular}{lllll}
\hline NO & Variabel Penelitian & B & S.E & Sig \\
\hline & Constanta & 0,161 & & 0.322 \\
\hline 1. & Pengetahuan & 0,445 & 0,077 & 0,000 \\
2. & Sikap & 0,410 & 0,073 & 0,000 \\
3. & Tindakan & 0,972 & 0,070 & 0,312 \\
\hline
\end{tabular}

Hasil uji statistik dengan menggunakan uji chi-square diperoleh bahwa nilai $\mathrm{p}=0.000(\mathrm{p}<0,05)$ hal ini menunjukkan bahwa ada hubungan antara pengetahuan penjamah makanan dengan hygiene penjamah makanan. Hasil uji statistik dengan menggunakan uji chisquare diperoleh bahwa nilai $\mathrm{p}=0.000(\mathrm{p}$ $<0,05)$ hal ini menunjukkan bahwa ada hubungan antara sikap penjamah makanan dengan hygiene penjamah makanan. Hasil uji statistik dengan menggunakan uji chisquare diperoleh bahwa nilai $\mathrm{p}=0.007$ ( $\mathrm{p}$ $<0,05)$ hal ini menunjukkan bahwa ada hubungan antara tindakan penjamah makanan dengan hygiene penjamah makanan.

Dari tabel 3 diatas dapat dilihat bahwa dari 3 (tiga) variabel penelitian yang telah signifikans pada uji bivariat dan dilanjutkan dengan analisis multivariate dengan menggunakan uji regresi linear berganda, maka hasil uji regresi menunjukkan faktor pengetahuan sangat berhubungan dengan hygiene penjamah makanan dengan nilai $\mathrm{p}=0,000$, faktor sikap dengan nilai $\mathrm{p}=0,000$. Sedangkan faktor tindakan tidak berhubungan dengan hygiene penjamah makanan dengan nilai $\mathrm{p}$ $=0,312$

\section{Pembahasan}

Hasil uji statistik dengan menggunakan uji chi-square diperoleh bahwa nilai $\mathrm{p}=0.470(\mathrm{p}>0,05)$ hal ini menunjukkan bahwa tidak ada hubungan antara kelompok umur penjamah makanan dengan hygiene penjamah makanan. umur tidak berhubungan dengan hygiene penjamah makanan karena terkait kepada sarana dan prasarana yang tersedia dan adanya dukungan dari pemilik rumah makan atau kantin. ${ }^{8}$

Seseorang yang memiliki masa kerja lebih lama akan memberikan respon yang lebih rasional dari pada pada mereka yang memiliki masa kerja yang lebih sedikit. Selain itu merekajuga akan lebih teliti dalam proses pengolahan makanan. ${ }^{8}$ Hasil uji statistik dengan menggunakan uji chisquare diperoleh bahwa nilai $\mathrm{p}=0.484$ ( $\mathrm{p}$ $>0,05$ ) hal ini menunjukkan bahwa tidak ada hubungan antara lama kerja penjamah makanan dengan hygiene penjamah makanan. Hasil uji statistik dengan menggunakan uji chi-square diperoleh bahwa nilai $\mathrm{p}=0.000(\mathrm{p}<0,05)$ hal ini menunjukkan bahwa ada hubungan antara pengetahuan penjamah makanan dengan hygiene penjamah makanan.

Berdasarkan hasil uji Chi-square diperoleh nilai probabilitas ( $p$ value $=$ $0,000<0,05)$ maka Ho ditolak dan $\mathrm{Ha}$ diterima, artinya terdapat hubungan yang signifikan antara pengetahuan dengan personal hygiene petugas penjamah makanan.Bahwa penjamah makanan yang sehat tentunya akan mempengaruhi kualitas makanan yang dikelola, sebab bila pengetahuan penjamah makanan tentang hygiene sanitasibaik, maka penerapan sanitasi hygiene pengelolaan makanan akan menjadi lebih baik sehingga terhindar dari kontaminasi sumber-sumber pencemaran. Pada usaha tata boga di katering penjamah makanan adalah ujung tombak penyelenggaraan pangan. Faktor kebersihan penjamah atau petugas makanan merupakan prosedur menjaga kebersihan dalam pengelolaan makanan yang aman dan sehat..$^{9}$ Hasil uji statistik 
dengan menggunakan uji chi-square diperoleh bahwa nilai $\mathrm{p}=0.000(\mathrm{p}<0,05)$ hal ini menunjukkan bahwa ada hubungan antara sikap penjamah makanan dengan hygiene penjamah makanan. Hasil penyebaran kuesioner menyatakan bahwa 36 orang responden tidak memiliki sertifikat kesehatan, penjamahm makanan pada umumnya mengetahui manfaat dari sertifikat kesehatan namun untuk memperoleh sertifikat tersebut tidak ada biaya yang diberikan oleh pihak pemilik rumah makan atau kantin, disamping itu pelayanan dari instansi terkait membebankan biaya sebagai pemeriksaan dan biaya sertifikat yang telah ditentukan sesuai dengan PMK NO. 21 Tahun 2013 tentang tarif Pendapatan Negara Bukan Pajak.

Berdasarkan data di KKP Kelas I Medan, bahwa Pada Tahun 2016 telah dilakukan pemeriksaan rectal swab terhadap 7 (tujuh) orang penjamah makanan dengan hasil penjamah makanan tidak ada yang menderita penyakit atau tidak ada yang mengandung bakteri salmonella. Dan berdasarkan kuesioner yang disebarkan kepada responden, bahwa keseluruhan responden tidak ada yang menderita penyakit menular.

Sanitasi merupakan bagian penting dalam pengolahan pangan yang harus dilaksanakan dengan baik. Sanitasi dapat didefinisikan sebagai usaha pencegahan penyakit dengan cara menghilangkan atau mengatur faktor-faktor lingkungan yang berkaitan dengan rantai perpindahan penyakit tersebut (Penjamah makanan adalah orang yang secara langsung berhubungan dengan makanan dan peralatan mulai dari tahap persiapan, pembersihan, pengolahan, pengangkutan sampai dengan penyajian. ${ }^{10}$ Hasil uji statistik dengan menggunakan uji chi-square diperoleh bahwa nilai $\mathrm{p}=0.007(\mathrm{p}<0,05)$ hal ini menunjukkan bahwa ada hubungan antara tindakan penjamah makanan dengan hygiene penjamah makanan.
Variable penelitian yang telah signifikans pada uji bivariat dan dilanjutkan dengan analisis multivariate dengan menggunakan uji regresi, maka hasil uji regresi menunjukkan faktor pengetahuan sangat berhubungan dengan hygiene penjamah makanan dengan nilai $\mathrm{p}$ $=0,000$, faktor sikap dengan nilai $\mathrm{p}=$ 0,000 . Sedangkan faktor tindakan tidak berhubungan dengan hygiene penjamah makanan dengan nilai $\mathrm{p}=0,312$

Penjamah makanan adalah orang yang secara langsung berhubungan dengan makanan dan peralatan mulai dari tahap persiapan, pembersihan, pengolahan, pengangkutan sampai dengan penyajian. Peran penjamah makanan sangat penting dan merupakan salah satu faktor dalam penyediaan makanan/minuman yang memenuhi syarat kesehatan.Personal hygiene dan perilaku sehat penjamah makanan harus diperhatikan. Seorang penjamah makanan harus beranggapan bahwa sanitasi makanan harus merupakan pandangan hidupnya serta menyadari akan pentingnya sanitasi makanan, hygiene perorangan dan mempunyai kebiasaan bekerja, minat maupun perilaku sehat. ${ }^{10}$

\section{Kesimpulan}

Perilaku hygiene penjamah makanan sebagian besar sudah sesuai dengan persyaratan. Hal ini berhubungan dengan pengetahuan, sikap, dan tindakan penjamah makanan Faktor pengetahuan dan sikap sangat berhubungan dengan hygiene penjamah makanan.

\section{Saran}

Diharapkan bagi penjamah makanan agar meningkatkan pengetahuannya dengan mengikuti pelatihan tentang sanitasi makanan yang dilakukan oleh instansi terkait seperti KKP Kelas I Medan, kesyahbandaran dan otoritas pelabuhan. Diharapkan kepada pemilik rumah makan/kantin agar menyediakan alat pelindung diri pada penjamah makanan seperti celemek, penutup kepala, masker 
dan sepatu boot. Bagi instansi terkait dalam hal ini adalah KKP Kelas I Medan membentuk suatu peraturan kepada pemilik rumah makan/kantin tentang kewajiban meyediakan alat pelindung diri bagi penjamah makanan.

\section{Daftar Pustaka}

1. Depkes RI, Kepmenkes RI No.431/Menkes/SK/IV/2007 tentang Pedoman Teknis pengendalian Risiko kesehatan Lingkungan di Pelabuhan/bandara/pos lintas batas dalam rangka karantina Kesehatan, Jakarta; 2009.

2. Fradiaz D. Kriteria dan Tata Laksana Penilaian Produk Pangan. Jakarta: Cetakan Indonesia; 2006.

3. Haryadi H. Sanitasi pengolahan bahan makanan. Cetakan kedua. Jakarta: Universitas Indonesia; 2009. perlu meningkatkan hygiene sanitasi penjamah makanan dengan cara

4. Arisman. Keracunan Makanan: Buku Ajaran Ilmu Gizi. Cetakan Pertama. Jakarta: EGC; 2012.

5. Dewanti. Keamanan pangan dalam siklus kehidupan; 2013. Available http://himitepa. Ik.ipb.ac.id/mencegah-keracunan-makanansiap-santap.

6. Peraturan Menteri Kesehatan No. 1096/MENKES/PER/2011 Tentang Kesehatan Pelabuhan 2015, Profil Kesehatan KKP Kelas I Medan

7. Notoatmodjo S. Promosi Kesehatan dan Ilmu Perilaku. Cetakan Pertama. Jakarta: PT. Asdi Mahasatya; 2007.

8. Marsaulina I. Studi Tentang Pengetahuan Perilaku dan Kebersihan Penjamah Makanan pada Tempat Umum Pariwista DI Jakarta; 2004.

9. Depkes RI, Keputusan Menteri Kesehatan No.715/MENKES/SK/V/2003; 2001.

10. World Health Organization. International Health Regulation 2005. Geneva; 2005. 